\title{
Value for Struggle of Main Character Novel Rembulan Tenggelam di Wajahmu by Tere Liye
}

\author{
Fadhlan Lazuardi ${ }^{1(*)}$ and Ermanto ${ }^{1}$
}

\author{
${ }^{1}$ Universitas Negeri Padang, Indonesia \\ *Corresponding author. Email: fadhlana637@ gmail.com ermanto@fbs.unp.ac.id
}

\begin{abstract}
The purpose of this research is how to describe the values of the struggle of the main character in the novel Rembulan Tenggelam di Wajahmu by Tere Liye based on the theory of literary sociology. The research design used was descriptive qualitative. Research data is presented based on the object of study that is not in the form of statistics or figures. While the research method is descriptive method. The object of study is the novel Rembulan Tenggelam di Wajahmu by Tere Liye. Data collection techniques in the form of literature study techniques. The results of this study can be concluded that there are three values of struggle in the novel Rembulan Tengrown Di Wajahmu by Tere Liye, namely the value of willingness to sacrifice, the value of unity, the value of price-respect.
\end{abstract}

Keywords: Struggle value, novel " rembulan tenggelam di wajahmu ", the main character

\section{INTRODUCTION}

A literary work is a picture of real life. Therefore, although a literary work is in the form of fiction, the problem presented by an author in it is inseparable from real-life experiences. It's just that in the delivery, the author often makes these literary works with different styles, and usually instill moral messages in them. Literary works that are able to attract the attention of readers usually contain stories that illustrate interesting phenomena that are or have happened in people's lives. The object of a literary work is the experience of human life, especially concerning social, cultural, artistic, religious, and thinking systems. Literature presents a picture of life, and life itself is a social reality (Damono, 1984: 1).

There are several kinds of literary works, one of which is a novel. The novel is a fictional story that tells the life of a person or a group of people written as interesting as possible by the author. One thing that becomes the focus of the contents of a novel is how the life journey of the characters contained in it. Therefore, in this research the thing that will be the focus of the research is the struggle of the characters from a novel titled Rembulan Tenggelam Di Wajahmu by Tere Liye. Novel Rembulan Tenggelam di Wajahmu that presents problems in his work with a complex plot. Tere Liye tries in each of his works to describe the flow of the mix through a good metaphysical journey (Kezia, 2017). Deeper learning to make sense of the meaning of the life of the main character of the novel Rembulan Tenggelam di Wajahmu. Because in the storyline the main character experiences two name changes. The change and change of name causes the main character to experience many complicated conflicts and so many struggles in it.

Value basically literally means good or strong. From this basic understanding, then expanded that value is everything that is liked, desired and aspired. Koentjaraningrat (in Joyomartono 1990: 12) defines cultural values as a conception that lives in the minds of the majority of the community about things that they must consider very valuable in life. Based on the understanding of the values above, then in general we can conclude that the value of struggle is something that is good, valuable, valuable, liked, and noble contained in an action taken by someone to face a problem or challenge in life, with goals and expectations that the action can produce a new condition that is better and more useful than the previous condition.

Because as long as we are alive, life's problems will always come to us, and that means that the struggle will continue and the values contained in the struggle will always accompany our steps in life. Consciously or unconsciously this value will arise or just born when we face a problem. Likewise with the characters in the novel Rembulan Tenggelam di Wajahmu.

\section{METHOD}

The research designused is descriptive qualitative. Generate research data in the form of words and sentences. Research data is presented based on the object of study that is not in the form of statistics or figures. While the research method is descriptive method. The method that 
describes the data related to the object of research studies which results in words and sentences. The description can be said as a presentation of information related to research data in the form of citations. The description in question is related to data on the value of struggle in the novel Rembulan Tenggelam di Wajahmu. A study also requires an approach. The approach in question is an approach as a researcher's perspective on the object of study. The approach used is in the form of qualitative literature, which is an approach with the object of study sourced from books and supported by literature that produces words and sentences.

The object of study is a literary work, which is a novel. The novel referred to in the study is Rembulan Drowning in Your Face by Tere Liye, 426 pages thick. Data collection techniques in the form of literature study techniques, by studying or saving and recording literary texts medalam. The data is based on sources that have been written in the novel Rembulan Tengrown di Wajahmu in the form of the character's struggle value.

\section{RESULTS AND DISCUSSION}

The Values of Struggle in the Novel Rembulan Tenggelam di Wajahmu

Face The values of struggle will usually be shown by someone when he has a problem in his life. The person will struggle with the goal of being able to escape from the problem and with the hope of getting a better life. The values of the struggle will encourage the birth of a new mental attitude, and which in turn guides the person to take a new, better action in an effort to face and resolve the life problems he is facing.

The values of the struggle is a value that has been inherent in our society for a long time. From the colonial period, our nation has been struggling to survive and the most important thing is to be able to expel the invaders from our country, and until now, even though our nation has been independent, but many life problems still approach our daily lives. Because indeed as long as we are alive, then life's problems will always come up to us, and that means that the struggle will continue and the values contained in the struggle will always accompany the steps of our lives.

Consciously or unconsciously this value will arise or just born when we face a problem. Likewise, the main character in the moonlight novel sinks in your face. He is named Ray.

So, the values of the struggle to be examined are the values of the struggle shown by the main character in the moonlight novel sinking in your face by Tere Liye. The main character goes through life starting from a place that children should not be in when he was a child. Orphanage. The values of the struggle contained in the moonlight novel sank in your face are as follows.

Value of Willing to Sacrifice

Being willing to sacrifice is an indispensable in carrying out a struggle. Because without sincere sacrifice, we will never achieve a great success in a struggle. In living this life, we will not always get everything we want, there will definitely be a problem that will come to us even though we never invited him to be present in our lives.

Indeed, that's what life is called, will always be full of challenges and something new. A new thing that we least expect to be present in our life's journey, it can appear without our expectation and we never think or estimate at all. Rehan sacrificed for something he wanted to buy. On that occasion, Rehan or Ray wanted to buy a crowbar from the sale of Eid parcel here. Consider the following quote.

"... Rehan pulled out a small crowbar. No money from selling the Eid parcel yesterday bought this little crowbar ... RDTW/39/4 "The

quote above explains that Rehan wants to buy a crowbar for capital in his next life. Rehan wants to get out and does not want to return to the place where he is, because there are too many questions and tortures he received while in the orphanage. The crowbar is the capital to steal a safe in the orphanage. Of course, the safe is very useful, because it is hidden by the orphanage guards. Rehan even jumped the windows of the orphanage swiftly and quickly. Without the slightest doubt in his heart.

The Value of Unity

The value of unity is a value that really needs to be owned by an individual. the value of unity is important for us to have, because it can maintain and maintain wholeness so as not to be scattered.

The value of unity can also lead us to get through each problem in a way together. If we go through or face a problem in a way together, then the problem will feel lighter and will be easier to solve. Because we will have other people who will help us to deal with the problem, in other words we will have sharing friends.

Various ethnic groups with diverse customs, various religions are embraced, the diversity of languages used is also easy to give an opportunity for differences. However, this difference can be eliminated if all parties have a strong sense of unity. the

Thus,foundation of our country, which reads Unity can actually be used as a guide to all the Indonesian people to interact, and is able to protect the nation and the whole of Indonesia. The value of unity can be seen in the following quotation.

"... trying to save you Ray, he does not know whether it is a redemption, but at the end of all these events, he regrets it ... RDTW/211/1"

In the above quotation explains that your strength is incomparable, it has been seen by Ray that Mother -ibu help her child in distress. Rey's role is to help the mother in saving her child and some people around the incident.

"... you know, that morning, the only sibling of your mother rushed to come from another city to make sure the train news was late ... RDTW/212/4" The

quote illustrates that Ray did not blame others for bad events happened to him. Other people will tend to reciprocate when others are not able to reply to others. But that was not done Ray.

Value Value-Respect

The attitude of respect for others is very important for us to have in the midst of our lives in society. We must be 
able to respect and respect the people around us. In the midst of differences in abilities and differences in the character they have, they are able to respect each other.

"... he wants to hold his wife when she finds out for the first time that they have just lost their jewels. Again. The doctor sighed. Allowing ... RDTW/308/3".

\section{CONCLUSION}

The main character is very central to something that is focused on the storyline of a literary work. The novel Rembulan Drowned in Your Face is depicted by Rehan's struggle which is clearly visible. The struggle began from his curiosity in knowing the origin of his own family. He was born as an orphanage taken care of by several people in it. The struggle in working to make a living and then habits that are regulated in all aspects, make the main character always independent in acting. The struggle carried out by Rehan was not always smooth. He was once chased by the police for stealing something. It can be concluded that humans can only do something beyond their abilities or beyond one's limitations. He can do things outside of himself and get rewarded in life.

Various forms of struggle by the main character have a positive or good impact on the reader. A positive thing can be in the form of patriotism in character. Precisely, willing to sacrifice and respect each other. Therefore, it can be imitated in real life that the attitudes and characters created by the author.

\section{ACKNOWLEDGMENTS}

author would like to thank Allah, Almighty, for providing the opportunity to complete writing this article. The ease that is obtained is also inseparable from the role of various parties. Acknowledgments also the authors say to Prof. Dr. Ermanto, M.Hum as the supervisor in writing this article. The author gets useful knowledge and constructive advice on this article.

\section{REFERENCES}

[1] Damono, Sapardi Djoko. (1984). Sosiologi Sastra sebuah pengantar ringkas. Jakarta: Pusat Pembinaan dan Pengembangan Bahasa Departemen Pendidikan dan Kebudayaan.

[2] Kezia, S. (2017). The values of the struggle of the main character in the novel Mata Air Mata by Hidayat Banjar: an analysis of literary sociology. Thesis. Indonesian Literature Department. (downloaded March 1, 2019).

[3] Muslim n. (2011). "Modernization in the novel shackles by Armijn Pane" a study of literary sociology".JOURNAL OF LANGUAGE, LITERATURE, AND CULTURE. Gorontalo: Volume 1, Number 1, MAY 2011.(downloaded March 1, 2019)

[4] Sabarudin, at all. (2016). The struggle of the main character in two dhonny dhirgantoro novels. Journal, Humanika No.16. Vol. 1. (downloaded March 1, 2019).

[5] Yahya (2016). The struggle of women to achieve independence in the social space of study of thenovel golden-toothed midah simanisby Pramodya Ananta Toer. Journal of Rhetoric, Volume 9, Number 1, February 2016, p. 1-89. 